\title{
Gastroretentive Floating Tablets Enclosing Nanosponge Loaded with Lafutidine for Gastric Ulcer: Formulation and Evaluation
}

\author{
Poornima, Sneh Priya* \\ Department of Pharmaceutics, NGSM Institute of Pharmaceutical Sciences (NGSMIPS), NITTE (Deemed to be University), Mangalore, \\ INDIA.
}

\begin{abstract}
Aim and Objectives: The present study aimed to formulate and evaluate gastroretentive nanosponge loaded with lafutidine for a gastric ulcer to overcome the drawbacks of oral conventional dosage forms such as the inability to confine and locate within the desired region of the gastrointestinal tract due to variable gastric emptying and motility. The floating tablets of nanosponge were formulated to increase the bioavailability of lafutidine by prolonging retention time in the upper gastric region. Materials and Methods: The emulsion solvent diffusion method was used to prepare the nanosponge and $3^{2}$ factorial design was employed to assess the influence of two independent variables ethyl cellulose: polyvinyl alcohol ratio and sonication time on particle size, entrapment efficiency and zeta potential of the prepared nanosponges. The optimized nanosponges were compressed into tablets by the direct compression method. Results: Statistical analysis revealed the significant effect of ethyl cellulose: polyvinyl alcohol ratio and sonication time on particle size, entrapment efficiency and zeta potential. The SEM images of the optimized formulation revealed the spherical shape and porous surface of the nanosponges. Pre and post-compression parameters of floating tablets found to be within the limit and the floating tablets of nanosponge remained buoyant for $24 \mathrm{~h}$ whereas nanosponges remained buoyant only for $7 \mathrm{~h}$. The F1 formulation showed short lag time, maximum drug content $(98.7 \%)$, sustained the drug release for $24 \mathrm{~h}$ and it was stable for the entire period study. Conclusion: The floating tablet of nanosponge is promising in retaining and controlling drug release for a pronged period of time in the stomach.
\end{abstract}

Key words: Nanosponge, Lafutidine, Design of experiment (DoE), Gastroretentive, Floating tablet.

\section{INTRODUCTION}

Even after the enormous development in drug delivery systems, the oral drug delivery system remains the most favored route of administration of drugs mainly due to ease of administration, patient compliance and low cost. ${ }^{1}$ The major drawback of conventional oral dosage forms is brief gastric emptying time. That leads to incomplete drug release from the delivery system resulting in reduced efficacy of dose. Numerous novel oral dosage forms have been developed to overcome the drawbacks with the conventional oral dosage forms and to target or localize the drugs to the target site.
One such approach is gastroretentive drug delivery system. It is a strategy for prolonging gastric residence time, thereby promoting site-specific release for local or systemic effects in the upper gastrointestinal tract (GIT). Gastroretentive formulations can remain in the gastric region for prolonged periods of time and thereby substantially increase the drug retention time (GRT). Several types of gastroretentive drug delivery strategies have been developed over the last few decades, including high density or sink systems which remain in the bottom of the stomach, low density or floating systems
Submission Date: 07-07-2020; Revision Date: 06-10-2020; Accepted Date: 11-01-2021

DOI: 10.5530/ijper.55.1s.41 Correspondence:

Dr. Sneh Priya Assistant Professor, NGSM Institute of Pharmaceutical Sciences, Deralakatte, Mangaluru-575018, Karnataka, INDIA. Phone no: +919916988245 Email id: snehpriya123@ nitte.edu.in

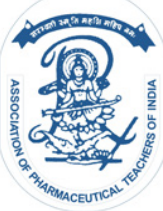

www.ijper.org 
that remains buoyant in gastric fluid, mucoadhesive systems that will adhere to stomach mucosa, unfoldable, extendable or swelling systems. ${ }^{2}$

Floating drug delivery systems float immediately after coming in contact with gastric fluid. This system has bulk density less than that of gastric fluid due to which it remain buoyancy in the gastric fluid without being affected by gastric emptying for prolonged period of time. Hence, improves the bioavailability of the drugs in absorption windows in the upper gastric regions. After the release of the drug residual system being emptied from the stomach. While the system floats on the gastric contents, the drug is gradually released from the system at the desired rate. Results of this gastro retention time increases and fluctuations in the plasma drug concentration are controlled. ${ }^{1,3}$

Nanosponge is a small solid particle with a porous surface and can be formulated as different dosage forms, such as oral, topical, parenteral and inhalational. The nanosponge dispersed with suitable excipients, diluents, lubricants and anti-caking agent forms tablets or capsule. The advantage of tablet or capsule dosage form is reduction of the overall dose, retention of the dosage form, reduction of toxicity and improvement of patient compliance by prolonged release. Simply combine nanosponge with sterile water, salt water or aqueous solution for parental administration. They can be formulated into topical hydrogel for topical administration. The spherical nanosponge has several pores where drugs can be stored and can precisely control the release rates or target drugs to a particular body site. ${ }^{4}$

Lafutidine is a second generation histamine $\mathrm{H}_{2}$-receptor antagonist that inhibits daytime (i.e. postprandial) and night time secretion of gastric acid in clinical studies. When compared to other $\mathrm{H}_{2}$ receptor antagonist lafutidine has 2-80 times higher receptor binding affinity. Due to the resulting reduction in gastric volume and acidity, lafutidine can be used in the treatment of gastrointestinal disorders. ${ }^{5}$ It has very low aqueous solubility and low bioavailability that impairs its dissolution in the upper gastric fluid which creates problems for the prepared systems. Ultimately, these aspects impede its therapeutic application by limiting the rate of absorption and thereby its activity. The solubility, permeability and rate of dissolution of a drug are key factors for assessing bioavailability. It is commercialized in Japan and India. ${ }^{6}$ Lafutidine has a short biological half-life and low bioavailability, it degrades in alkaline condition but remains stable in acidic condition so that dosage form which prolongs gastric residence time in stomach can reduce the frequency of dosing and also increase the bioavailability. Therefore the objective of the study was to formulate and characterize gastroretentive nanosponge loaded with lafutidine for controlled release.

\section{MATERIALS AND METHODS}

\section{Materials}

Lafutidine was gifted by Zuventus Healthcare Ltd., Mumbai, India. Ethyl cellulose and sodium bicarbonate was procured from Himedia Laboratories, Mumbai, India. Polyvinyl alcohol, dichloromethane, talc and magnesium stearate were procured from Loba chemie, Mumbai. HPMC K15M, HPMC K100M and microcrystalline cellulose were procured from Yarrow Chem Products, Mumbai.

\section{Methods}

\section{Design and Preparation of Lafutidine Nanosponge Experimental Design}

For optimization of the formulation, a full factorial design was implemented using Design Expert ${ }^{\circledR}$ software. A $3^{2}$ factorial design approach was employed to assess the influence of two independent variables, namely ethyl cellulose: Poly vinyl alcohol (PVA) ratio $\left(\mathrm{X}_{1}\right)$ and sonication time $\left(\mathrm{X}_{2}\right)$ on particle size $\left(\mathrm{Y}_{1}\right)$, entrapment efficiency $\left(\mathrm{Y}_{2}\right)$ and zeta potential $\left(\mathrm{Y}_{3}\right)$ of prepared nanosponge 7 . Combination of three levels of each variable with one center point resulted in total 10 formulations as shown in the Table 1 and 2 .

\section{Formulation of Nanosponge}

Required quantities of ethyl cellulose, polyvinyl alcohol (PVA) were weighed accurately along with the measured quantity of dichloromethane (DCM) and distilled water (Table 2). Ethyl cellulose and weighed amount of drug were dissolved in $20 \mathrm{ml}$ of dichloromethane forms the disperse phase. The disperse phase was then slowly added to distilled water containing specified amount of PVA with continuous stirring. This is then sonicated for specific time in a probe sonicator and again stirring was carried out in a magnetic stirrer to remove excess of dichloromethane. Obtained nano suspension was then

\begin{tabular}{|c|c|c|c|}
\hline \multicolumn{4}{|c|}{ Table 1: Levels and factors. } \\
\hline \multirow{2}{*}{ Factors } & \multicolumn{3}{|c|}{ Levels } \\
\cline { 2 - 4 } & -1 & 0 & $\mathbf{+ 1}$ \\
\hline $\mathrm{X}_{1}(\mathrm{EC}: \mathrm{PVA})(\mathrm{w} / \mathrm{w})$ & $1: 1$ & $1: 2$ & $1: 3$ \\
\hline $\mathrm{X}_{2}$ (Sonication Time $\left.(\mathrm{m})\right)$ & 10 & 15 & 20 \\
\hline Dependable Variable & \multicolumn{3}{|c|}{$\begin{array}{c}\text { Particle Size }\left(\mathrm{Y}_{1}\right) \\
\text { \% Entrapment Efficiency }\left(\mathrm{Y}_{2}\right) \\
\text { Zeta potential }\left(\mathrm{Y}_{3}\right)\end{array}$} \\
\hline
\end{tabular}


Table 2: Composition of Nanosponge as per $3^{2}$ full factorial designs.

\begin{tabular}{|c|c|c|c|c|c|}
\hline \multicolumn{2}{|c|}{ Table 2: Composition of Nanosponge as per $\mathbf{3}^{2}$ full factorial designs. } \\
\hline $\begin{array}{c}\text { Formulation } \\
\text { code }\end{array}$ & Drug (mg) & $\begin{array}{c}\text { Ethyl Cellulose } \\
(\mathbf{m g})\end{array}$ & $\begin{array}{c}\text { Polyvinyl alcohol } \\
(\mathbf{m g})\end{array}$ & $\begin{array}{c}\text { Dichloromethane } \\
(\mathbf{m l})\end{array}$ & Distilled water (ml) \\
\hline F1 & 200 & 1000 & 1000 & 20 & 100 \\
\hline F2 & 200 & 1000 & 2000 & 20 & 100 \\
\hline F3 & 200 & 1000 & 3000 & 20 & 100 \\
\hline F4 & 200 & 1000 & 1000 & 20 & 100 \\
\hline F5 & 200 & 1000 & 2000 & 20 & 100 \\
\hline F6 & 200 & 1000 & 3000 & 20 & 100 \\
\hline F7 & 200 & 1000 & 1000 & 20 & 100 \\
\hline F8 & 200 & 1000 & 2000 & 20 & 100 \\
\hline F9 & 200 & 1000 & 3000 & 20 & 100 \\
\hline F10 & 200 & 1000 & 2000 & & 100 \\
\hline
\end{tabular}

filtered and nanosponges were collected and dried at room temperature for $24 \mathrm{~h} .{ }^{7,8}$

\section{Particle size, Zeta Potential and PDI}

Particle size, zeta potential and PDI are the most important factors for nano formulations. The particle charge and movement velocity of the particles in an electric field is indicated by zeta potential whereas PDI value indicates particle distribution in the given sample. The average particle size, zeta potential and PDI were measured by Malvern zeta sizer at fixed temperature of $25^{\circ} \mathrm{C}$. Formulation was suitably diluted with distilled water and measured for the above parameters. ${ }^{4,9}$

\section{Percentage Entrapment Efficiency}

For the determination of the entrapment of the formulation, nanosponge equivalent to $100 \mathrm{mg}$ of lafutidine was weighed and powdered in mortar then placed in $100 \mathrm{ml}$ standard flask containing $10 \mathrm{ml}$ of methanol and volume was made up to the mark using $0.1 \mathrm{~N} \mathrm{HCl}$ of $\mathrm{pH} 1.2$ and kept aside for $24 \mathrm{~h}$. Then filtered using whatmann filter paper and concentration of lafutidine present in the solution were analysed by UV spectroscopic method at $286 \mathrm{~nm}$. The percentage entrapment efficiency was calculated using the following formula. ${ }^{10}$

$\%$ Entrapment efficiency $=\frac{\text { Actual drug content in nanosponge }}{\text { Theoretical drug content }} \times 100$

\section{Optimization of Nanosponges}

The nanosponges were optimized based on the responses with minimum particle size, maximum entrapment efficiency and zeta potential within range and the software generated a solution with desirability more than 0.9. The optimized formulation was prepared by taking 1:3 ratio of EC: PVA and sonication time $13.199 \mathrm{~m}$.

\section{FTIR Study}

Fourier transform infrared (FTIR) spectroscopy was performed using a Shimadzu FTIR 8300 Spectrophotometer and from 4000 to $400 \mathrm{~cm}^{-1}$ region, the spectrum was recorded. The drug was dispersed in $\mathrm{KBr}(200-400 \mathrm{mg})$ and made into disc form by compressing it with a pressure of 5 tons for $5 \mathrm{~min}$ in a hydraulic press and the spectrum was obtained. The compatibility of the optimized nanosponges with the formulation ingredients was determined and compared with the FT-IR peak of pure lafutidine. ${ }^{11,12}$

\section{Percentage yield}

The lafutidine nanosponges obtained after drying was weighed. Percentage yield value was calculated as follows: ${ }^{13}$

$$
\% \text { Yield }=\frac{\text { Weight of nanosponge }}{\text { Total solid weight }} \times 100
$$

\section{Scanning Electron Microscopy}

The shape and morphology of the nanosponges can be determined by Scanning Electron Microscopy. The morphological evaluation of nanosponge was carried out by SEM. Sample was deposited on a glass slide and was kept under vacuum. The samples were coated with a thin gold/palladium layer using a sputter coater unit. The scanning electron microscope was operated at an acceleration voltage of $15 \mathrm{kV}^{4}$

\section{Formulation and Evaluation of Floating tablets of nanosponge loaded with lafutidine}

\section{Pre-compression Parameters}

Before the compression, powder blend were evaluated for parameters like bulk density and tapped density from 
these Carr's index and Hausner's ratio were calculated. The Flow property of the powder blend was evaluated by angle of repose. ${ }^{14,15}$

\section{Formulation of floating tablets of nanosponge loaded with lafutidine}

The floating tablets of lafutidine loaded nanosponges were prepared by direct compression method. The composition of the floating tablets of the nanosponge loaded lafutidine is shown in the Table 3. To prepare floating tablets of nanosponge two different polymers like HPMC K100M and HPMC K15M selected. HPMC K15M, HPMC K100M, Sodium bicarbonate were passed through the sieve no 60 separately. All the ingredients were mixed together and blended with talc and magnesium stearate. These blended powders were compressed into tablets using $8 \mathrm{~mm}$ flat faced round tooling on a single punch tablet machine (Rimek mini press II). Compression force was set to get tablets with hardness $4-5 \mathrm{~kg} / \mathrm{cm}^{2}$. Four formulations were prepared and coded them from F1 to F4. ${ }^{16,17}$

\section{Evaluation of the floating tablets of nanosponge loaded with lafutidine \\ Post-compression parameters}

Tablets were evaluated for post-compression parameters like weight variation, hardness, thickness, friability and drug content. The three tablets were randomly selected and evaluated hardness and thickness using Monsanto hardness tester and Vernier caliper, respectively. Twenty tablets randomly selected from each batch and evaluated for weight variation test. The friability of the tablets was evaluated by Roche friabilitor taking six tablets from each batch and percentage friability was determined. ${ }^{16,17}$

\section{Drug content}

The floating tablets of nanosponges were evaluated for its drug content. Four tablets were finely powdered and the powder equivalent to $10 \mathrm{mg}$ of lafutidine was weighed accurately and transferred to a $100 \mathrm{ml}$ volumetric flask. The volume was made up to $100 \mathrm{ml}$ by $0.1 \mathrm{~N} \mathrm{HCl}$ of

Table 3: Composition of each $200 \mathrm{mg}$ of floating tablets of nanosponge loaded with lafutidine.

\begin{tabular}{|c|c|c|c|c|}
\hline Formulation & F1 & F2 & F3 & F4 \\
\hline $\begin{array}{c}\text { Nanosponge } \\
\text { (Equivalent to 10 mg of drug) }\end{array}$ & 26 & 26 & 26 & 26 \\
\hline HPMC K15 M & - & - & 50 & 75 \\
\hline $\mathrm{HPMC} \mathrm{K100} \mathrm{M}^{\mathrm{NaHCO}} \mathrm{H}_{3}$ & 50 & 75 & - & - \\
\hline Talc & 30 & 30 & 30 & 30 \\
\hline Magnesium stearate & 2 & 2 & 2 & 2 \\
\hline Microcrystalline Cellulose & 2 & 2 & 2 & 2 \\
\hline
\end{tabular}

$\mathrm{pH} 1.2$ kept for stirring under mechanical stirring for 30 $\mathrm{m}$. The solution was filtered and necessary diluted and absorbance was taken at $286 \mathrm{~nm}$ using UV spectrometer. The linearity equation obtained from calibration curve was used for the estimation of lafutidine content in the tablets. ${ }^{18,19}$

\section{In-vitro buoyancy study}

The in-vitro buoyancy study of optimized floating tablet and optimized nanosponge was determined by placing tablet/ nanosponges in a $200 \mathrm{ml}$ beaker containing 100 $\mathrm{ml}$ of $0.1 \mathrm{~N} \mathrm{HCl}, \mathrm{pH}$ 1.2. Physical state of the tablet and nanosponge was observed for $24 \mathrm{~h}$. The time between tablet/ nanosponge introduction to its buoyancy on the $0.1 \mathrm{~N} \mathrm{HCl}$ (lag time) and the time during which tablets/ nanosponge remains buoyant (total buoyancy time) were visually determined and compared. ${ }^{12,16}$

\section{Swelling study}

The floating tablets of nanosponges were weighed individually (noted as initial weight) and placed separately in a beaker containing $200 \mathrm{ml}$ of $0.1 \mathrm{~N} \mathrm{HCl}$ (at room-temperature) and at regular intervals floating tablets were removed from the beaker and the with the help of tissue paper excess liquid from the surface was removed and reweighed (swollen weight of tablet). The percentage swelling was calculated from the following equation: ${ }^{20}$

$$
\% \text { Swelling }=\frac{\begin{array}{l}
\text { Weight of swollen tablet }- \\
\text { Initial weight of tablet }
\end{array}}{\text { Initial weight of tablet }} \times 100
$$

\section{In-vitro drug release}

The in-vitro drug release was performed using USP type II apparatus (paddle type) at $50 \mathrm{rpm}$. The in vitro dissolution study performed using $500 \mathrm{ml}$ of dissolution media i.e, $0.1 \mathrm{~N} \mathrm{HCl}$ maintained at $37^{\circ} \mathrm{C} \pm 0.5^{\circ} \mathrm{C}$. At predetermined intervals aliquots was withdrawn and same volume of fresh pre-warmed dissolution medium was replaced to the dissolution apparatus. The study was conducted for $24 \mathrm{~h}$. The samples were filtered through whatman filter paper and diluted to suitable concentration using 0.1 $\mathrm{NHCl}$ and absorbance was taken at $286 \mathrm{~nm}$ using UV spectrometer. ${ }^{21-23}$

\section{Drug release kinetics and mechanism of release}

The obtained data from the dissolution study was subjected to kinetic analysis of first order (log cumulative $\%$ vs time) and zero order kinetics (cumulative amount of drug released vs time). Mechanism of drug release was determined by fitting the data to Higuchi's matrix 
model (cumulative $\%$ of drug release vs square root of time) and Korsmeyer-peppas model (log cumulative percentage of drug released vs log time). ${ }^{21}$

\section{Stability Studies}

The optimized floating tablet of nanosponge (F1) was stored in a glass container with rubber cap as a closure and tightly sealed. The stability studies were carried out as according to $\mathrm{ICH}$ guidelines at different temperature conditions, i.e., room temperature $25^{\circ} \mathrm{C} \pm$ $2^{\circ} \mathrm{C} / 60 \% \mathrm{RH} \pm 5 \% \mathrm{RH}$ and accelerated temperature $40 \pm 2{ }^{\circ} \mathrm{C} / 75 \%+5 \% \mathrm{RH}$ for a period of 3 months. The sample periodically withdrawn (1,2 and 3 month) and evaluated for visual appearance, average weight, thickness, hardness, buoyancy lag time, total buoyancy time anddrug content. ${ }^{22}$

\section{RESULTS AND DISCUSSION}

\section{Formulation and characterization of Lafutidine loaded nanosponge}

\section{Statistical analysis of design of experiment}

The nanosponges were prepared by emulsion solvent diffusion method by varying the concentration of polymers. A $3^{2}$ full factorial design was applied to assess the influence of independent variables such as ethyl cellulose: polyvinyl alcohol ration and sonication time on responses such as particle, zeta potential and $\%$ entrapment efficiency of prepared nanosponges. Statistical analyzed showed that independent variables have significant $(P<0.05)$ effect on responses. The responses were given in the Table 4.

\section{Particle Size}

The mean particle size of nanosponge is shown in the Table 4 and Figure 1. The mean particle size of nanosponge was ranged from 234.5 to $284.1 \mathrm{~nm}$. All the ten nanosponge formulations showed particle size in the nanorange $(<1 \mu \mathrm{m})$. The effect of stabilizer and sonication time on particle size was obtained from $3^{2}$ full factorial experimental designs. Results showed that when there was an increase in the PVA concentration and sonication time there was significant decrease in the particle size. When there is increase in the stabilizer concentration there is decrease in the particle size this could be because when the stabilizer concentration increases there will be less aggregation of the particle results in decrease in particle size. As the sonication time increases particle gets reduced. The $3 \mathrm{D}$ response surface plot of the effects of ethyl cellulose: PVA ratio and sonication time on the particle size is shown in the Figure 1 and it clearly shows the variables effects and interaction effect of variables on particle size. The

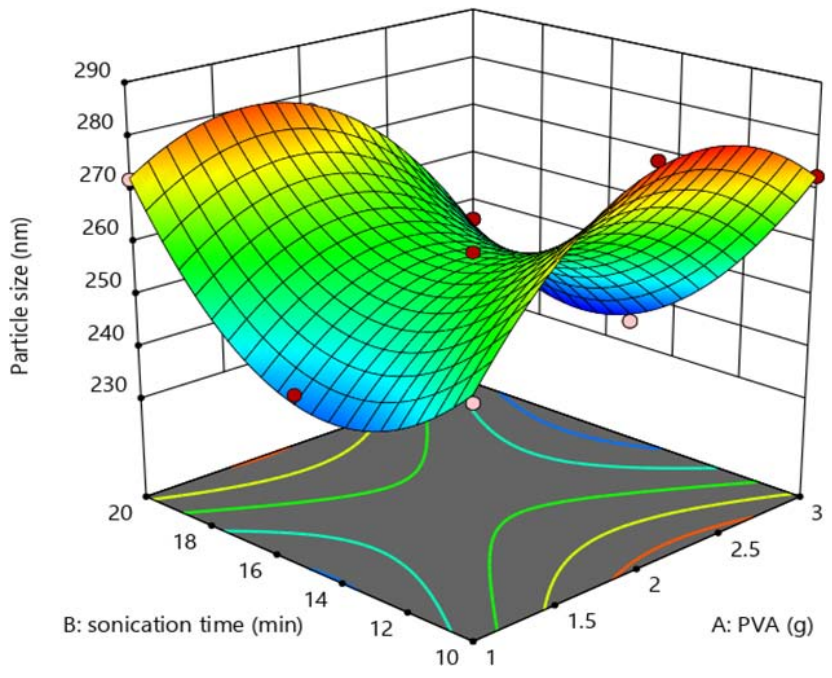

Figure 1: 3D Response surface curve depicting the effect of polyvinyl alcohol and sonication time on the particle size of nanosponge.

\begin{tabular}{|c|c|c|c|c|c|c|c|}
\hline \multirow{2}{*}{ Form. Code } & X1 & X2 & Y1 & Y2 & Y3 & Yield (\%) & \multirow{2}{*}{ PDI } \\
\cline { 2 - 6 } & EC:PVA & $\begin{array}{c}\text { Sonication } \\
\text { time }\end{array}$ & $\begin{array}{c}\text { Particle size } \\
\text { (nm) }\end{array}$ & $\begin{array}{c}\text { Zeta potential } \\
\text { (mV) }\end{array}$ & $\begin{array}{c}\text { Entrapment } \\
\text { Efficiency (\%) }\end{array}$ & \\
\hline F1 & $1: 1$ & 10 & 252.5 & -14.3 & 71.44 & 20.38 & 0.152 \\
\hline F2 & $1: 2$ & 10 & 284.1 & -32.8 & 68.92 & 16.16 & 0.137 \\
\hline F3 & $1: 3$ & 10 & 272.7 & -31.7 & 97.18 & 14.58 & 0.175 \\
\hline F4 & $1: 1$ & 15 & 242.2 & -31.6 & 41.68 & 15.33 & 0.201 \\
\hline F5 & $1: 2$ & 15 & 258.4 & -31.09 & 34.28 & 28.58 & 0.118 \\
\hline F6 & $1: 3$ & 15 & 234.5 & -26.6 & 58.54 & 36.58 & 0.126 \\
\hline F7 & $1: 1$ & 20 & 272.1 & -38.2 & 41.24 & 21.47 & 0.171 \\
\hline F8 & $1: 2$ & 20 & 277.1 & -33 & 33.42 & 14.58 & 0.102 \\
\hline F9 & $1: 3$ & 20 & 246.2 & -26.8 & 63.53 & 23.97 & 0.154 \\
\hline F10 & $1: 2$ & 15 & 256.9 & -32.6 & 35.38 & 30.45 & 0.248 \\
\hline
\end{tabular}


quadratic equation generated from the analysis is given as follows:

Particle Size $=+257.77-2.23(\mathrm{~A}) *-2.32(\mathrm{~B}) *-11.52$

$$
(\mathrm{AB})^{*}-19.54\left(\mathrm{~A}^{2}\right) *+22.71\left(\mathrm{~B}^{2}\right) *
$$

Here A, B represents EC: PVA ratio and sonication time respectively and ' $*$ ' indicates significance of the variables. The developed regression model was found to be statistically significant $(p<0.05)$ with a high adjusted $R^{2}$ value of 0.9876 . The model has curvature at higher levels of formulation variables which indicates the significance of quadratic term $\mathrm{B}^{2}$ on particle size as shown in Table 5.

\section{Zeta potential}

The zeta potential values indicate the charge of the particles thereby indicates the stability of the formulation. The obtained zeta potential values of the formulations are given the Table 4 . The results showed that zeta potential was deceases with increase concentration of PVP and sonication time. Increased zeta potential value indicates greater stability of the formulation. The zeta potential values ranged from -26 to $-38 \mathrm{mV}$. Increase in the stabilizer concentration increases the stability of the formulation thereby increases zeta potential values. The regression analysis was applied to study the effect of variables on particle size. The two Factor Interaction (2FI) model was found significant with model $f$-value of 5.57 and predicted $R^{2}$ of -0.2458 and adjusted $R^{2}$ of 0.9876. A negative predicted $R^{2}$ here implies that the overall mean may be a better predictor of response than the current model or in some cases, a higher order model may also predict better. The equation generated from the analysis is given as follows:

$$
\begin{aligned}
\text { Zeta potential }= & -29.87-0.1667 \mathrm{~A}^{*}-3.20 \mathrm{~B}^{*} \\
& +7.20 \mathrm{AB}^{*}
\end{aligned}
$$

The equations shows that the both the variables have significant effect on the response. The interaction effect of the variables also found to be significant for the response i.e. zeta potential as shown in the Figure 2.

\section{Entrapment efficiency}

The percentage entrapment efficiency of nanosponge is shown in the Table 4 and 5 . The percentage entrapment efficiency of nanosponge was ranged from 50-70\%. The effect of stabilizer and sonication time on particle size was obtained from $3^{2}$ full factorial experimental designs and showed that the stabilizer concentration has positive effect whereas sonication time has negative effect on the $\%$ entrapment efficiency. As the concentration of PVA increases entrapment efficiency also increases the reason could be that when there is increase in the stabilizer concentration it forms wall thickness of the nanosponge increases and due to which higher amount of drug entrapped within the nanosponges. The decrease in the entrapment efficiency with the increase in the sonication time could be because it leaches the outer layer of the nanosponge during sonication so that smaller sized nanosponge forms thereby, entrapment efficiency decreases. The interaction effect of both the variables forms the nanosponge with the minimum size and maximum entrapment efficiency. The quadratic equation generated from the analysis is given as follows:

$$
\begin{aligned}
\mathrm{E} . \mathrm{E}= & +34.29+10.81(\mathrm{~A}) *-16.56(\mathrm{~B}) *-0.8625(\mathrm{AB}) * \\
& +16.36\left(\mathrm{~A}^{2}\right) *+17.42\left(\mathrm{~B}^{2}\right)^{*}
\end{aligned}
$$

\begin{tabular}{|c|c|c|c|c|c|c|c|}
\hline \multirow[t]{2}{*}{$\begin{array}{l}\text { Sl. } \\
\text { No }\end{array}$} & \multirow[t]{2}{*}{ Factor } & \multicolumn{2}{|c|}{$\begin{array}{c}\text { Particle size } \\
\text { (Adjusted } R^{2}=0.9876 \text { ) }\end{array}$} & \multicolumn{2}{|c|}{$\begin{array}{l}\text { \%Entrapment efficiency } \\
\text { (Adjusted } R^{2}=0.9864 \text { ) }\end{array}$} & \multicolumn{2}{|c|}{$\begin{array}{c}\text { Zeta potential } \\
\text { (Adjusted } R^{2}=0.6035 \text { ) }\end{array}$} \\
\hline & & $\beta$ coefficient & 'P' value & $\beta$ coefficient & ' $P$ ' value & $\beta$ coefficient & ' $P$ ' value \\
\hline 1. & Intercept & +257.77 & 0.0001 & +34.29 & 0.0002 & -29.87 & 0.0361 \\
\hline 2. & A- EC:PVA & -2.23 & 0.0398 & +10.81 & 0.0004 & -0.1667 & 0.9223 \\
\hline 3. & B-Sonication time & -2.32 & 0.0357 & -16.56 & $<0.0001$ & -3.20 & 0.0986 \\
\hline 4. & $A B$ & -11.52 & 0.0002 & -0.8625 & 0.5200 & +7.20 & 0.0115 \\
\hline 5. & $A^{2}$ & -19.54 & $<0.0001$ & +16.36 & 0.0005 & - & - \\
\hline 6. & $B^{2}$ & +22.71 & $<0.0001$ & +17.42 & 0.0004 & - & - \\
\hline
\end{tabular}

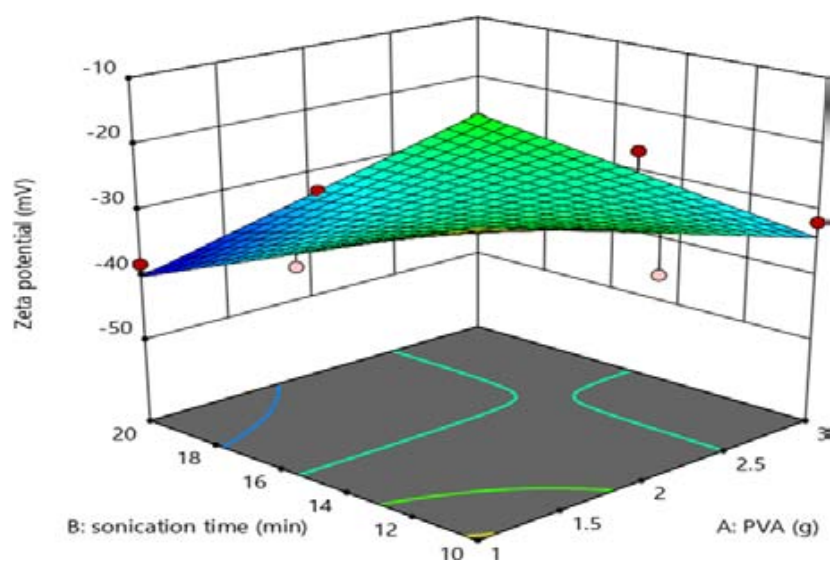

Figure 2: 3D Response surface curve depicting the effect of polyvinyl alcohol and sonication time on the zeta potential of nanosponges. 
The equations shows that the both the variables have significant effect on the response. The model found to have curvature at higher levels of formulation variables indicates the significance of quadratic term $\mathrm{B}^{2}$ on entrapment efficiency as a shown in the Figure 3.

\section{Optimization of nanosponges}

The optimized batch was formulated by using 1:3 ratio of EC: PVA and 13 min sonication, respectively and again analysed for particle size, zeta potential and entrapment efficiency. The observed response of the optimized formulation was found to be within 95\% confidence interval of the predicted one which is acceptable as shown in the Table 6 and Figure 4 and 5.

\section{PDI and Percentage Yield}

PDI and percentage yield of the formulations ranged from $0.1-0.25$ and $14-37 \%$ respectively. And it was found that both the percentage yield and PDI was not significantly affected by independent variables.

\section{FTIR study}

FT-IR spectra of the pure lafutidine and optimized lafutidine loaded nanosponges were compared and observed that there was no major changes in the spectra

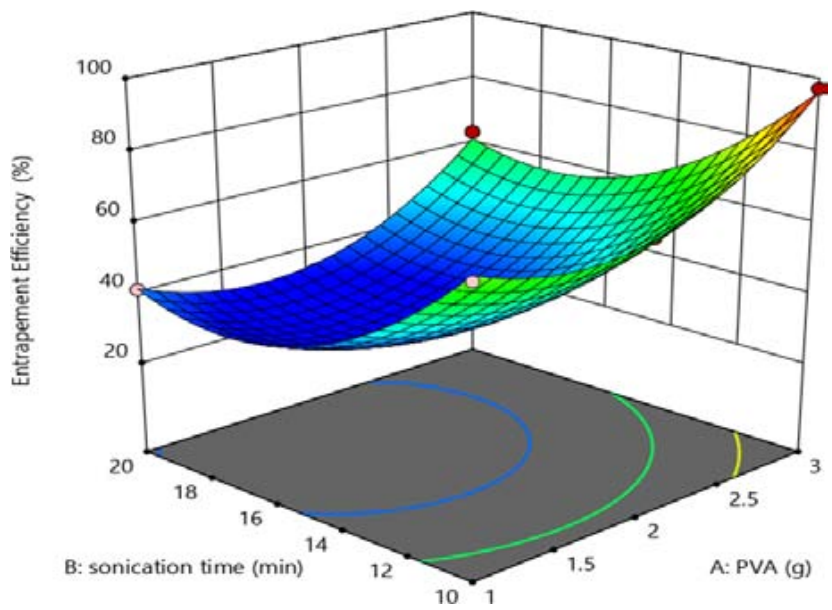

Figure 3: 3D Response surface curve depicting the effect of polyvinyl alcohol and sonication time on the \% entrapment efficiency of nanosponge. indicates that there was no incompatibility between them as shown in the Table 7 and Figure $6 \mathrm{a}$ and $6 \mathrm{~b}$.

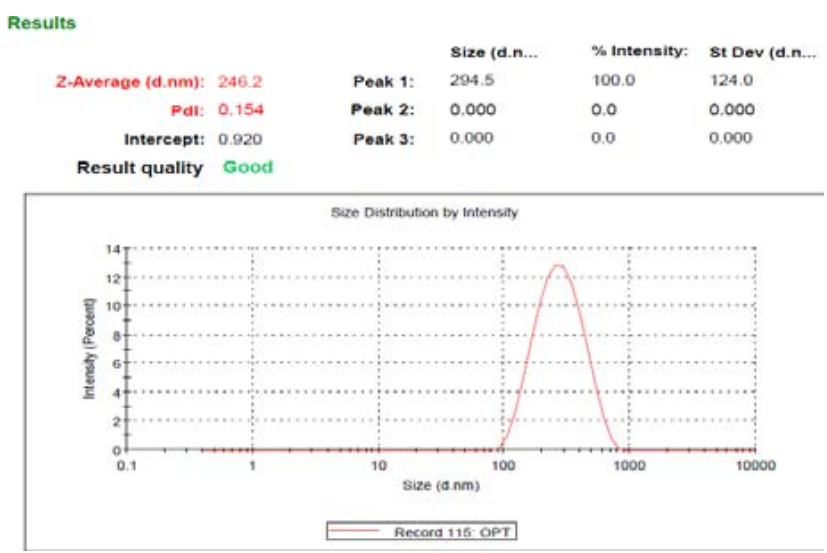

Figure 4: Particle size analysis of optimized formulation by Zeta sizer.

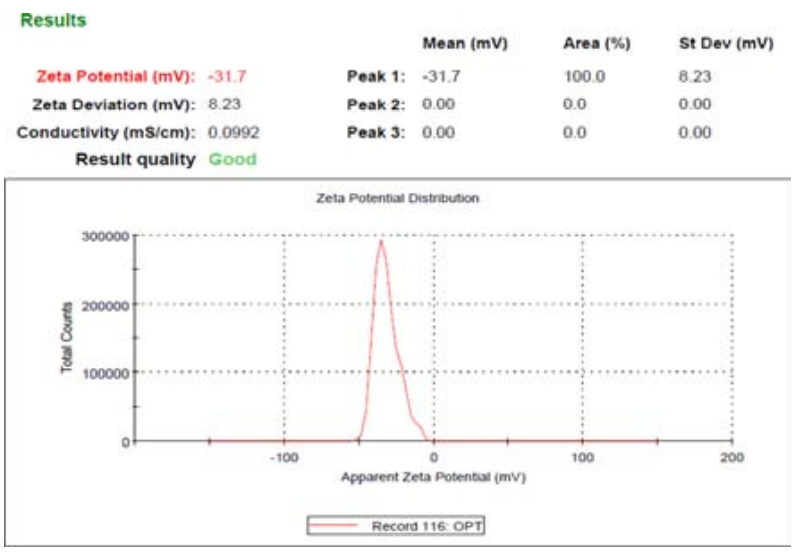

Figure 5: Zeta potential analysis of optimized formulation by zeta sizer.

\begin{tabular}{|c|c|c|}
\multicolumn{3}{|c|}{ Table 7: Major IR peaks of pure Lafutidine and } \\
optimized formulation. \\
Sample & Composition & Major peaks $\left(\mathbf{c m}^{-1}\right)$ \\
\hline A & $\begin{array}{c}\text { Pure } \\
\text { Lafutidine }\end{array}$ & $\begin{array}{c}3282.84,2931.73,2791.00, \\
1656.42,1609.02,1542.76, \\
1400.97,1294.86,1117.21,1032.43\end{array}$ \\
\hline B & $\begin{array}{c}\text { Optimized } \\
\text { nanosponge } \\
\text { formulation }\end{array}$ & $\begin{array}{c}3501.24,2974.11,2870.95, \\
1442.84,1373.54,1061.81,917.57\end{array}$ \\
\hline
\end{tabular}

Table 6: Point prediction of optimized batch with $95 \%$ confidence interval.

\begin{tabular}{|c|c|c|c|c|c|}
\hline Response & Predicted Mean & Observed & Std Dev & 95\% PI low & 95\% PI high \\
\hline Particle size & 243.924 & 246.2 & 1.82139 & 237.708 & 250.14 \\
\hline PDI & 0.1584 & 0.154 & 0.0430225 & 0.0563261 & 0.260474 \\
\hline Zeta potential & -31.4761 & -31.7 & 4.0131 & -42.761 & -20.1911 \\
\hline \% Entrapment Efficiency & 69.9999 & 70.96 & 2.44884 & 61.6424 & 78.3573 \\
\hline Yield & 25.254 & 24 & 1.43739 & -8.84898 & 59.357 \\
\hline
\end{tabular}




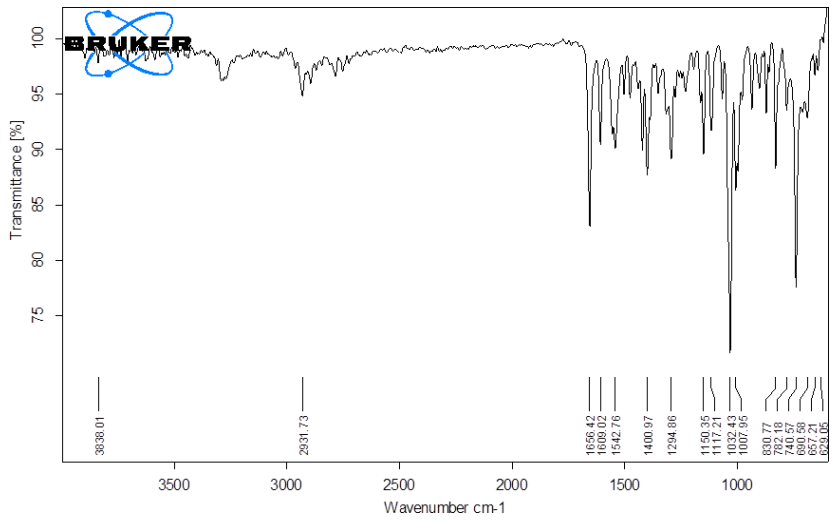

Figure 6a: FTIR Spectrum of Lafutidine.

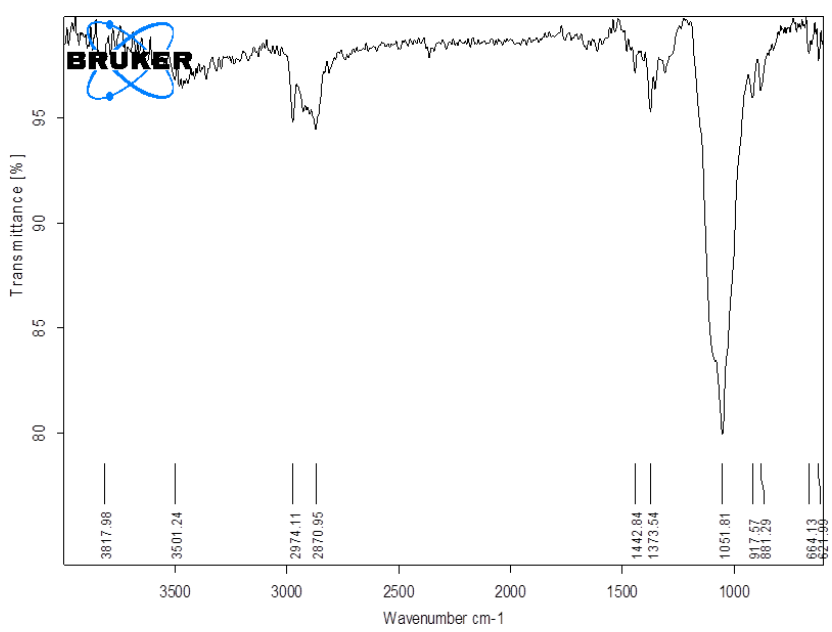

Figure 6b: FTIR spectrum of optimized formulation of nanosponge.

\section{Shape and morphology}

The surface morphological analysis of optimized formulation was carried out using scanning electron microscopy. The results revealed that the particles were porous in nature, spherical in shape and uniform in size and distribution as shown in Figure 7.

\section{Formulation and Evaluation of Floating tablets of nanosponge loaded with Lafutidine \\ Preformulation studies}

The floating of nanosponge loaded with lafutidine was prepared using effervescent technology by direct compression method. The pre and post-compression parameters of all the four tablets i.e. F1, F2, F3 and F4 were found to be within the I.P limit for uncoated tablets as shown in Table 8 and 9.

\section{In vitro buoyancy study}

All the floating tablets were formulated by effervescent approach. On immersion of tablets in $0.1 \mathrm{~N} \mathrm{HCl}$ of $\mathrm{pH} 1.2$ solution $\left(37 \pm 0.5^{\circ} \mathrm{C}\right)$ all the floating tablets

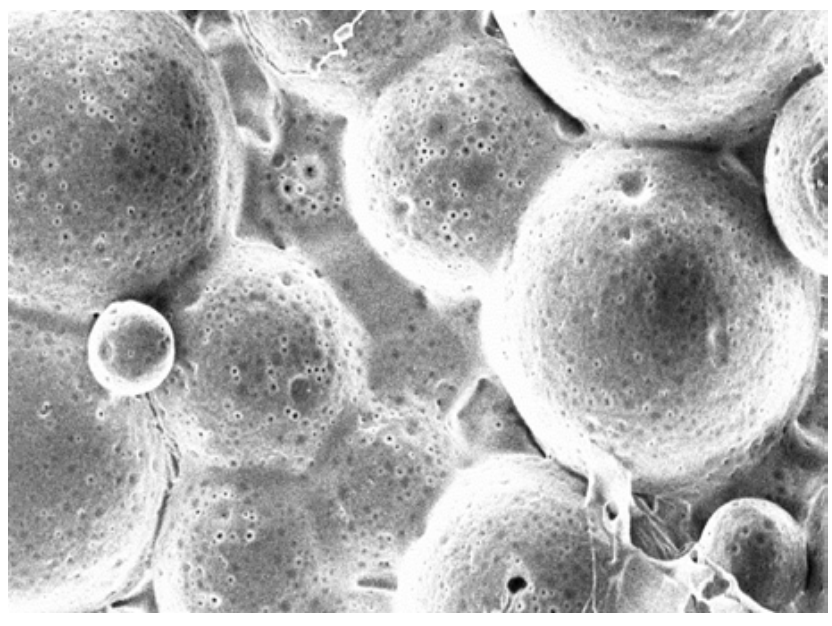

Figure 7: SEM image of optimized nanosponge formulation.
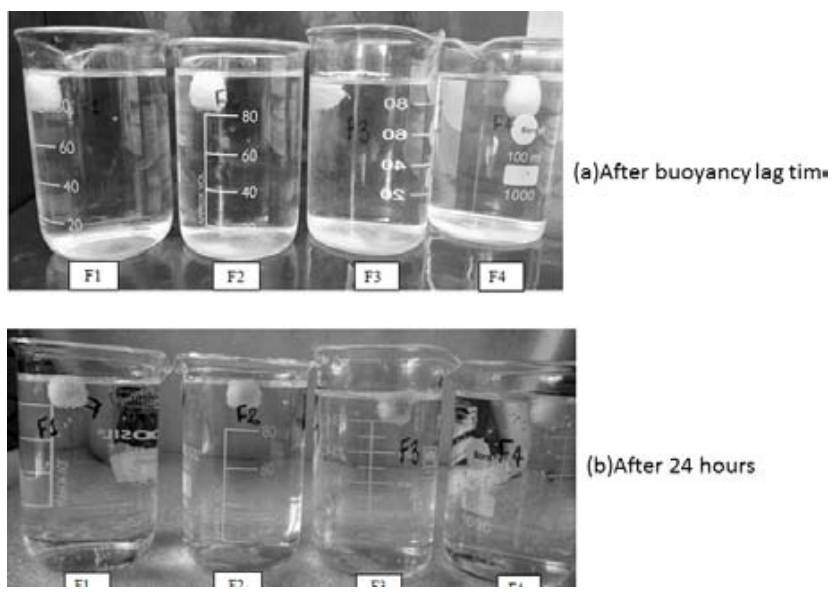

Figure 8: In vitro buoyancy study of floating tablets of Lafutidine loaded nanosponge in $0.1 \mathrm{~N} \mathrm{HCl}, \mathrm{pH} 1.2$.

floated immediately and remained buoyant up to $24 \mathrm{~h}$ without being disintegrated as shown in the Figure 8 . The buoyancy of the tablets was induced by sodium bicarbonate and microcrystalline cellulose. The tablets showed shortest buoyancy lag time and remained buoyant for $24 \mathrm{~h}$. The reason could be that the gas generated within the tablet during the process was protected by the gel formed by hydration of polymer which lead to reduction in tablet density $(>1)$ and thereby tablet becomes buoyant. F1 shows shortest lag time (01:08 m) when compared to other three formulations and all the four formulations remains buoyant up to $24 \mathrm{~h}$ (Table 10).

\section{Swelling Study}

Swelling index is also an important factor which ensures the buoyancy and drug dissolution of the matrix tablet. Immediately after the tablet was introduced to the $0.1 \mathrm{~N}$ $\mathrm{HCl}(\mathrm{pH} 1.2)$ a gel layer was formed around the tablet core which determines its release from the matrix tablets. The swelling property of the tablet is mainly due 
Table 8: Pre compression Flow Properties of granule.

\begin{tabular}{|c|c|c|c|c|c|}
\hline Formulation & Angle repose $\left.\mathbf{~}^{\mathbf{}}\right)$ & Bulk density $\mathbf{( g / \mathbf { c m } ^ { 2 } )}$ & Tapped density $\left(\mathbf{g} / \mathbf{c m}^{2}\right)$ & Hausner's ratio & Carr's index \\
\hline F1 & $29.06 \pm 0.753$ & $0.331 \pm 0.002$ & $0.386 \pm 0.001$ & 1.166 & 14.248 \\
\hline F2 & $24.82 \pm 0.272$ & $0.329 \pm 0.005$ & $0.364 \pm 0.001$ & 1.106 & 9.615 \\
\hline F3 & $26.81 \pm 0.192$ & $0.347 \pm 0.001$ & $0.394 \pm 0.004$ & 1.135 & 11.928 \\
\hline F4 & $25.98 \pm 0.4714$ & $0.353 \pm 0.001$ & $0.387 \pm 0.0037$ & 1.096 & 8.785 \\
\hline
\end{tabular}

*Each value is average of triplicates

\section{Table 9: Post-compression properties of floating tablet nanosponge loaded with lafutidine.}

\begin{tabular}{|c|c|c|c|c|c|}
\hline \multicolumn{6}{|c|}{ Table 9: Post-compression properties of floating tablet nanosponge loaded with lafutidine. } \\
\hline Formulation & $\begin{array}{c}\text { Weight variation } \\
(\boldsymbol{n}=\mathbf{3})\end{array}$ & $\begin{array}{c}\text { Thickness } \mathbf{( m m )} \\
(\boldsymbol{n}=\mathbf{3})\end{array}$ & $\begin{array}{c}\text { Hardness } \mathbf{( K g / \mathbf { c m } ^ { 2 } )} \\
(\boldsymbol{n}=\mathbf{3})\end{array}$ & Friability (\%) $(\boldsymbol{n = 6 )}$ & Drug content (\%) \\
\hline F1 & $200.26 \pm 0.371$ & 3.02 & $4.56 \pm 0.471$ & $0.957 \pm 0.621$ & $98.7 \pm 0.265$ \\
\hline F2 & $200.25 \pm 0.261$ & 3.02 & $3.67 \pm 0.471$ & $0.406 \pm 0.164$ & $99.3 \pm 0.215$ \\
\hline F3 & $200.15 \pm 0.255$ & 3.02 & $5.34 \pm 0.471$ & $0.668 \pm 0.207$ & $85.71 \pm 0.423$ \\
\hline F4 & $200.3 \pm 0.315$ & 3.02 & $3.34 \pm 0.471$ & $0.549 \pm 0.321$ & $88.96 \pm 0.235$ \\
\hline
\end{tabular}

*Each value is average of triplicates

Table 10: In-vitro buoyancy study of optimized nanosponge and floating tablets.

\begin{tabular}{|c|c|c|c|}
\hline SI. No & Formulation & $\begin{array}{c}\text { Floating lag time } \\
\text { (min) }\end{array}$ & $\begin{array}{c}\text { Total floating } \\
\text { time (hr) }\end{array}$ \\
\hline 1. & $\begin{array}{c}\text { Optimized } \\
\text { nanosponge }\end{array}$ & 4.06 & 7 \\
\hline 2. & F1 & $01: 08$ & $>24$ \\
\hline 3. & F2 & $06: 52$ & $>24$ \\
\hline 4. & F3 & 04 & $>24$ \\
\hline 5. & F4 & $11: 84$ & $>24$ \\
\hline
\end{tabular}

\begin{tabular}{|c|c|c|c|c|}
\hline \multirow{2}{*}{$\begin{array}{l}\text { Time } \\
\text { (hrs) }\end{array}$} & \multicolumn{4}{|c|}{ \% Swelling index } \\
\hline & F1 & F2 & F3 & F4 \\
\hline 0.5 & $10.86 \pm 0.274$ & $10.62 \pm 0.78$ & $18.37 \pm 0.514$ & $21.50 \pm 0.615$ \\
\hline 1 & $26.87 \pm 0.179$ & $42.43 \pm 0.522$ & $39.34 \pm 0.375$ & $35.21 \pm 0.946$ \\
\hline 2 & $39.06 \pm 0.755$ & $72.12 \pm 0.702$ & $60.65 \pm 0.959$ & $51.78 \pm 0.798$ \\
\hline 4 & $67.18 \pm 0.602$ & $83.78 \pm 0.878$ & $70.47 \pm 0.694$ & $70.90 \pm 0.697$ \\
\hline 6 & $70.94 \pm 0.988$ & $86.85 \pm 0.616$ & $88.49 \pm 0.356$ & $82.21 \pm 0.285$ \\
\hline 8 & $89.57 \pm 0.446$ & $111.43 \pm 0.575$ & $95.35 \pm 0.547$ & $91.72 \pm 0.542$ \\
\hline 10 & $98.04 \pm 0.861$ & - & $104.46 \pm 0.8$ & $98.56 \pm 0.44$ \\
\hline
\end{tabular}

*Each value is average of triplicates

to the polymer used. The higher concentration polymer showed faster swelling of the tablet as shown in Table 11.

\section{In-vitro drug release}

The dissolution profile of tablet formulations (F1, F2, F3, F4) showed sustained release when compared to the nanosponge formulation which shows faster release (Figure 9). The Figure 10 shows that the optimized floating tablet of lafutidine loaded nanosponge shows controlled

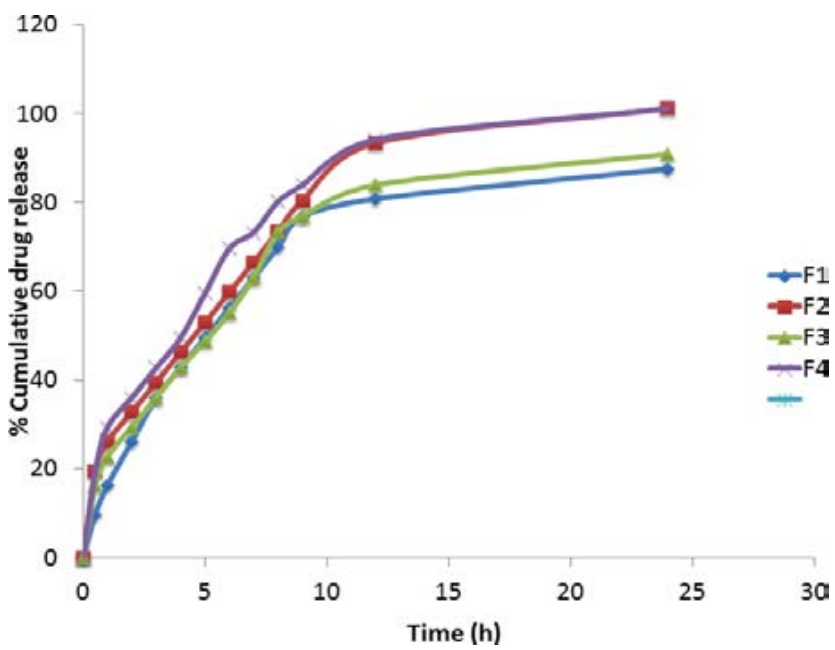

Figure 9: Comparative in vitro drug release study of floating tablet of Lafutidine loaded nanosponge.

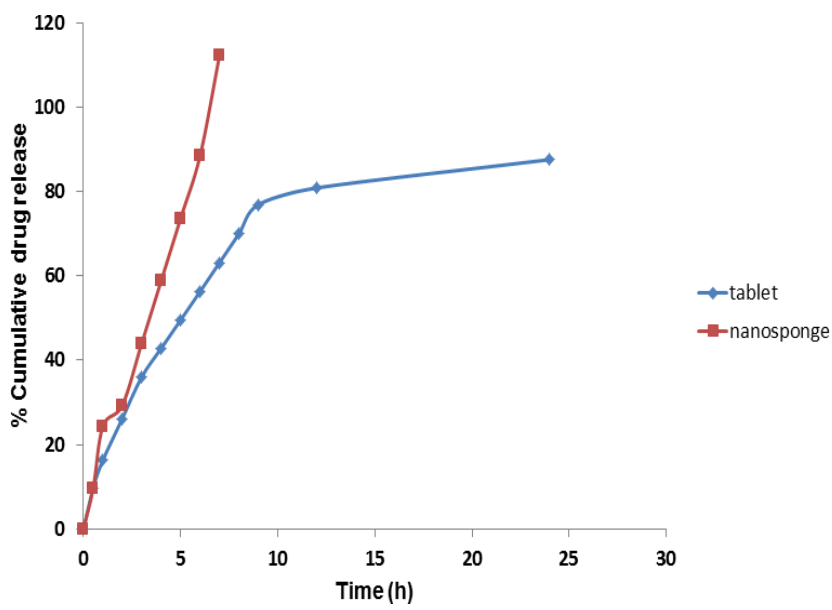

Figure 10: Comparative in vitro drug release study of optimized nanosponge with floating tablets of Lafutidine loaded in nanosponge. 
Table 12: Comparison of in vitro drug release kinetics of optimized nanosponge with floating tablet of Lafutidine loaded nanosponge.

\begin{tabular}{|c|c|c|c|c|c|c|c|c|c|}
\hline \multirow[t]{3}{*}{ F. code } & \multicolumn{9}{|c|}{ Kinetic models } \\
\hline & \multicolumn{2}{|c|}{ Zero order } & \multicolumn{2}{|c|}{ First order } & \multicolumn{2}{|c|}{ Higuchi } & \multicolumn{3}{|c|}{ Korsmeyer-peppas } \\
\hline & $R^{2}$ & $\mathbf{K}$ & $R^{2}$ & $\mathbf{K}$ & $R^{2}$ & $\mathbf{K}$ & $R^{2}$ & $\mathbf{K}$ & $\mathbf{n}$ \\
\hline Nanosponge & 0.985 & -14.726 & 0.7583 & -0.2411 & 0.9384 & 48.87 & 0.9514 & 1.278 & 0.70 \\
\hline $\mathrm{F} 1$ & 0.7103 & -3.374 & 0.876 & -0.0395 & 0.9966 & 27.434 & 0.9994 & 1.207 & 0.73 \\
\hline $\mathrm{F} 2$ & 0.8008 & -0.162 & 0.976 & -0.0847 & 0.9847 & 23.647 & 0.9882 & 1.409 & 0.45 \\
\hline F3 & 0.7523 & -3.3445 & 0.9156 & -0.0446 & 0.9835 & 23.223 & 0.9931 & 1.346 & 0.48 \\
\hline $\mathrm{F} 4$ & 0.7423 & -3.5424 & 0.9838 & -0.0848 & 0.9764 & 27.374 & 0.9835 & 1.435 & 0.46 \\
\hline
\end{tabular}

\begin{tabular}{|c|c|c|c|c|c|c|c|c|}
\hline \multirow{2}{*}{ Parameters } & \multicolumn{4}{|c|}{$25^{\circ} \mathrm{C} \pm 2^{\circ} \mathrm{C} / 60 \% \mathrm{RH} \pm 5 \% \mathrm{RH}$} & \multicolumn{4}{|c|}{$40^{\circ} \mathrm{C} \pm 2^{\circ} \mathrm{C} / 75 \% \mathrm{RH} \pm 5 \% \mathrm{RH}$ (Accelerated) } \\
\hline & Initial & 1 Month & 2 Month & 3 Month & Initial & 1 Month & 2 Month & 3 Month \\
\hline Appearance & \multicolumn{8}{|c|}{ White to off white tablet } \\
\hline Average weight (mg) & 200.33 & 200.33 & 200 & 200.33 & 200 & 200 & 200.33 & 200.66 \\
\hline Thickness (mm) & 3.02 & 3.02 & 3.03 & 3.03 & 3.02 & 3.02 & 3.04 & 3.04 \\
\hline Hardness $\left(\mathrm{Kg} / \mathrm{cm}^{2}\right)$ & 4.56 & 4.56 & 4.56 & 4.56 & 4.67 & 4.67 & 4.67 & 4.70 \\
\hline Buoyancy lag time(min) & 1.08 & 1.22 & 1.25 & 1.24 & 1.05 & 1.02 & 1.06 & 1.08 \\
\hline Total buoyancy time (hr) & $>24$ & $>24$ & $>24$ & $>24$ & $>24$ & $>24$ & $>24$ & $>24$ \\
\hline$\%$ Drug content & 98.7 & 98.33 & 98.33 & 98.33 & 97.84 & 97.84 & 97.84 & 97.84 \\
\hline
\end{tabular}

release compared to nanosponge formulation. The maximum amount of drug that has been released from the optimized formulation after $24 \mathrm{~h}$ was found to be $87.54 \%$ whereas nanosponge released $88.40 \%$ of the drug within $7 \mathrm{~h}$. This implies that the floating tablets of lafutidine loaded nanosponge resulted in the prolonged release of the drug.

\section{Drug release kinetics}

Released data were fitted to kinetic models in order to investigate the drug release kinetics (Table 12). As per the highest linearity regression coefficient $\left(R^{2}\right)$, it was found that nanosponge formulation and all tablets formulations were best fitted to Zero order and First order respectively. The drug release mechanism of floating tablets was studied by comparing Higuchi model and Korsemeyer-peppas exponential model. Nanosponge and all tablets formulation were found to show good linearity regression coefficient $\left(R^{2}\right)$ for Korsmeyer-peppas model than Huguchi model. The release exponent (n) was found to be more than 0.45 for most of the formulations that characterized release of drug by Non-Fickian (anomalous) diffusion, which may indicate that the drug release rate is controlled by more than one mechanism i.e. diffusion coupled with erosion mechanism.

\section{Stability Studies}

The stability study of the optimized formulation F1 was conducted as per the ICH guideline. The study was conducted for three month and analyzed for any changes in visual appearance, average weight, thickness, hardness, buoyancy lag time, total buoyancy time and drug content. Stability study results indicated that the there was no significant change in the above parameters as shown in the Table 13.

\section{CONCLUSION}

The nanosponges were prepared by emulsion solvent diffusion method and optimized by using $3^{2}$ factorial designs. The statistical analysis revealed the significant effect variables on responses. The observed values for particle size, zeta potential and \% entrapment efficiency of the optimized nanosponge was found to be within $95 \%$ confidence interval of the predicted one which is acceptable. The optimized nanosponges were spherical, porous in nature. The floating tablets of nanosponge loaded with lafutidine were prepared by using effervescent technology using different grades of polymers. The pre and post-compression parameters of all the four tablets i.e. F1, F2, F3 and F4 were found to be within the I.P limit for uncoated tablet. Through in-vitro buoyancy 
study it can be concluded that F1 tablets shows better buoyancy time when compared to Nanosponges. The in-vitro drug release studies results showed that there was complete drug release from nanosponges within 7 $\mathrm{h}$ whereas the floating tablet showed controlled release of the drug up to $24 \mathrm{~h}$. The optimized F1 formulation showed maximum drug content of $98.7 \%$ and when compared to other formulations had shortest buoyancy lag time of 01:08 $\mathrm{m}$ and the F1 floating tablet showed controlled drug release for prolonged period of time. The optimized F1 tablet remained stable during the entire period of study when stored at different temperatures and humidity conditions.

Hence, it can be concluded that the floating tablet of nanosponge loaded with lafutidine can be an effective drug delivery system for gastric ulcer with controlled drug release.

\section{ACKNOWLEDGEMENT}

Authors are thankful to Zuventus Healthcare for providing the gift samples of lafutidine. The authors are also thankful to NGSM Institute of Pharmaceutical Sciences, Mangalore for providing necessary facility to carry out the research work.

\section{CONFLICT OF INTEREST}

Authors do not have any conflict of interest

\section{ABBREVIATIONS}

SEM: Scanning electron microscopy; $\mu \mathrm{g}$ : Microgram; FT-IR: Fourier transform infrared spectroscopy; PDI: Poly dispersity index; EC: Ethyl cellulose; PVA: Polyvinyl alcohol; $\beta$ : Estimated -beta.

\section{REFERENCES}

1. Nayak AK, Malakar J, Sen KK. Gastroretentive drug delivery technologies: Current approaches and future potential. J Pharm Educ Res. 2010;1(2):1-12.

2. Nikalje AP, Tiwari S, Kamble S. Mucoadhesive: As Oral Controlled Gastroretentive Drug Delivery System. Int J Res Pharm Sci. 2012;2(3):32-59.

3. Lopes CM, Bettencourt C, Rossi A, Buttini F, Barata P. Overview on gastroretentive drug delivery systems for improving drug bioavailability. Int J Pharm. 2016;510(1):144-58.

4. Penjuri SCB, Ravouru N, Damineni S, Bns S, Poreddy SR. Formulation and evaluation of lansoprazole loaded nanosponge. Turk J Pharm Sci. 2016;13(3):304-10.
5. Sindhoor SM, Priya S, Maxwell A. Formulation and Evaluation of Novel in situ Gel of Lafutidine for Gastro Retentive Drug Delivery. Asian J Pharm Clin Res. 2018;11(8):88-94.

6. Fule R, Amin P. Development and evaluation of lafutidine solid dispersion via hot melt extrusion: Investigating drug-polymer miscibility with advanced characterization. Asian J Pharm Sci. 2014;9(2):92-106.

7. Aldeswari HM, Badr-Eldin SM, Labib GS, Kamel AH. Design and formulation of a topical hydrogel integrating lemongrass-loaded nanosponges with an enhanced antifungal effect: In vitrol in vivo evaluation. Int J Nanomedicine. 2015;10:893-902.

8. Srinivas P, Sreeja K. Formulation and Evaluation of Voriconazole Loaded Nanosponges for Oral and Topical Delivery. Int J Drug Dev and Res. 2013;5(1):55-69.

9. Omar SM, Ibrahim F, Ismail A. Formulation and evaluation of cyclodextrin-based nanosponges of griseofulvin as pediatric oral liquid dosage form for enhancing bioavailability and masking bitter taste. Saudi Pharm J. 2020;28(3):349-61.

10. Francis DJE, Yusuf FS. Development and Evaluation of Nanosponges Loaded Extended Release Tablets of Lansoprazole. Univers J Pharm Res. 2019;4(1):24-8.

11. Vageesh NM, Sura RS, Begum KG, Swathi B. Formulation Development and in vitro Evaluation of Floating Tablets of Lafutidine by Employing Effervescent Technology. Asian J Pharm Res. 2017;7(3):189-97.

12. Galatage ST, Bhaishaikh IM, Kadam VP, et al. Floating Microsponges as Gastro Retentive Drug Delivery System Containing Lafutidine to Treat Gastric Ulcer. Acta Sci Pharm Sci. 2019;3(2):3-12.

13. Solunke RS, Borge UR, Murthy KR, Deshmukh MT, Shete RV. Formulation and evaluation of gliclazide nanosponges. Int J Appl Pharm. 2019;11(6):181-9.

14. Amit P, Kumar JS, Harishankar P, Tarkeshwar S, Arpit S. Formulation Development and Evaluation of Famotidine Floating Tablet. Int J Pharm Sci Rev Res. 2010;4(3)224-9.

15. Sahu H, Jain V, Upmanyu N, Mishra SS, Raghuwanshi N. Formulation and evaluation of effervescent floating tablets of levofloxacin. Der Pharmacia Lettre. 2011;3(6):272-9.

16. Pawar HA, Gharat PR, Dhavale RV, Joshi PR, Rakshit PP. Development and Evaluation of Gastroretentive Floating Tablets of an Antihypertensive Drug Using Hydrogenated Cottonseed Oil. Int Sch Res Notices. 2013;1-9.

17. Nanjwade BK, Adichwal SA, Nanjwade VK, Gaikwad KR, et al. Development and Evaluation of Gastroretentive Floating Tablets of Glipizide Based on Effervescent Technology. J Drug Metab Toxicol. 2012;3(3):1-5.

18. Shah KU, Khan GM. Regulating drug release behavior and kinetics from matrix tablets based on fine particle-sized ethyl cellulose ether derivatives: An in vitro and in vivo evaluation. Sci World J. 2012;1-8. doi:10.1100/2012/842348

19. Kumar R, Patil MB, Pati SR, Paschapur MS. Formulation and Evaluation of Effervescent Floating Tablet of Famotidine. Int $\mathrm{J}$ Pharmtech Res. 2009;1(3):754-63.

20. Patil H, Prashar B, Chandel A, Thakur V. Formulation and Evaluation of Floating Tablet of Pantoprazole Sodium Sequihydrate. J Pharm Res. 2012;5(9):4659-62.

21. Gharti KP, Thapa P, Budhathoki U, Bhargava A. Formulation and in-vitro evaluation of floating tablets of hydroxypropyl methylcellulose and polyethylene oxide using ranitidine hydrochloride as model drug. J Young Pharm. 2012;4(4):201-8.

22. Sarangapani S, Bangaru J, Rajappan M. In vitro and in vivo Evaluation of the Gastroretentive Floating Dosage form. Int Res J Pharm. 2014;5(9):695-700.

23. Patil SH, Talele GS. Formulation development and in vitro and in vivo evaluation of gastroretentive floating drug delivery system of Lafutidine. Asian J Pharm. 2013;7(2):68-74. 


\section{PICTORIAL ABSTRACT}

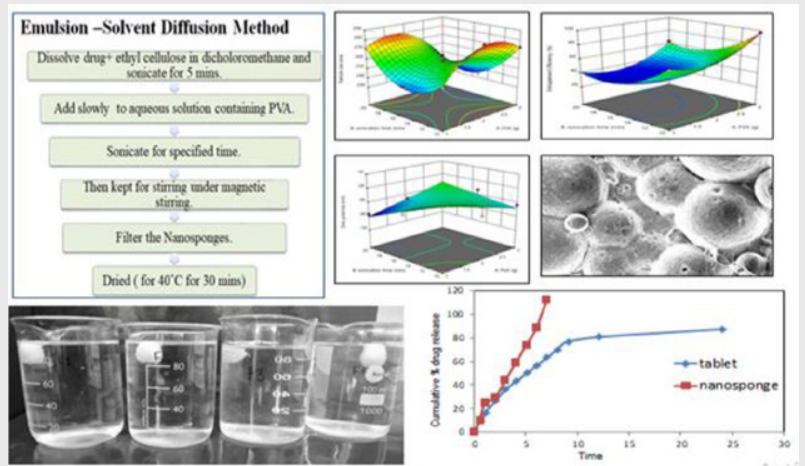

\section{SUMMARY}

Nanosponges were prepared by emulsion solvent diffusion method. A $3^{2}$ factorial approach was used to assess the influence of independent such EC: PVA ratio and sonication time on particle size, zeta potential and $\%$ entrapment efficiency. Statistical analysis revealed the significant effect of variables on response. The nanosponge optimized based on minimum particle size, maximum entrapment and zeta potential in range with desirability more than 0.9. The optimized nanosponge had spherical shape and porous in nature. The optimized formulation was compressed in to tablets. In-vitro buoyancy results showed that F1 tablets showed better buoyancy compared to nanosponge. In-vitro drug release results showed F1 floating tablets shows better release and controlled the release for $24 \mathrm{~h}$ when compared to nanosponge which shows complete drug release within $7 \mathrm{~h}$. Optimized floating tablet of nanosponge loaded with lafutidine remained stable for entire period of the study

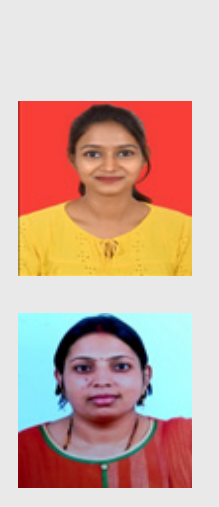

\section{About Authors}

Ms. Poornima is currently working in Microlabs Limited, Goa as management trainee in production department. She pursued her M Pharm in Pharmaceutics at NGSM Institute of Pharmaceutical Sciences, NITTE (Deemed to be University), Mangalore. Her area of research is novel drug delivery systems such as nano formulation.

Dr. Sneh Priya is currently working as assistant professor in NGSM Institute of Pharmaceutical Sciences. She had more than 9 year experience in research and academic field. Her research areas of interest are nano formulation, ethosomes, transfersomes and buccal drug delivery system.

Cite this article: Poornima, Priya S. Gastroretentive Floating Tablets Enclosing Nanosponge Loaded with Lafutidine for Gastric Ulcer: Formulation and Evaluation. Indian J of Pharmaceutical Education and Research. $2021 ; 55(1 \mathrm{~s}):$ s $100-\mathrm{s} 111$. 